p-ISSN 2614-1221

http://jep.ppj.unp.ac.id/index.php/jep

Doi: https://doi.org/10.24036/jep/vol2-iss2/245

\title{
Validitas dan Praktikalitas Lembar Kerja Peserta Didik (LKPD) Materi Kingdom Plantae Berbasis Pendekatan Saintifik untuk Peserta Didik Kelas X SMA/MA
}

\author{
Lasmi Lestari ${ }^{1)}$ Heffi Alberida ${ }^{2)}$ Yosi Laila Rahmi ${ }^{3)}$ \\ ${ }^{1)}$ Program Studi Pendidikan Biologi Jurusan Biologi, FMIPA, Universitas Negeri Padang \\ ${ }^{2,3)}$ Staf Pengajar Jurusan Biologi, FMIPA, Universitas Negeri Padang \\ Email.lasmilestari95@gmail.com, alberidamatua@gmail.com,yosibio@fmipa.unp.ac.id
}

\begin{abstract}
This is a development research to produce valid and practice Student Worksheet. This research used 3 steps from 4-D models those are defined, design and development. The subject of this research was 28 students class $X$ from SMA Negeri 1 Padang, validated by 2 lecturers and 2 teachers. The object of this research was based student worksheet that validated by 4 validators. The data in this research are primary data consisting of validity and practicality. The result of validity was $87,30 \%$ with criteria valid, practicality by teachers was very practiced with value $85,94 \%$ and by the student was practicing with value $83,05 \%$.
\end{abstract}

Keywords: Student Worksheet, Scientific approach, 4-D

\section{PENDAHULUAN}

Pendekatan saintifik dalam proses pembelajaran menekankan pada kerja sama antara peserta didik dalam menyelesaikan permasalahan. Proses pendekatan saintifik meliputi beberapa kegiatan, yakni menga-mati, menanya, mengolah informasi, mengasosiasikan dan mengomunikasikan. Menurut Hosnan (2014) pendekatan saintifik adalah pembelajaran yang menuntut partisi-pasi aktif peserta didik mengonstruk konsep, hukum atau prinsip melalui kegiatan mengamati, menanya, mengumpulkan infor-masi, mengasosiasi dan mengomunikasikan. Penerapan pendekatan saintifik pada pembelajaran dilakukan pada tahap kegiatan inti. Pendekatan saintifik dalam pembe-lajaran dapat memicu keaktifan peserta didik. Hal ini sesuai dengan hasil penelitian Marjan (2014) pembelajaran dengan pendekatan saintifik dapat meningkatkan hasil belajar biologi dan keaktifan peserta didik.

Penerapan pendekatan saintifik pada proses pembelajaran bisa diintegrasikan kepada bahan ajar seperti modul, handout, buku, LKPD dan sebagainya. Menurut Majid (2012) bahan ajar adalah segala bentuk bahan yang memudahkan guru dalam proses pembelajaran. Selain itu menurut Rahmi, dkk (2017) bahan ajar tidak hanya berguna bagi pendidik tetapi juga bagi peserta didik untuk menjadi pedoman aktivitasnya dalam pembelajaran. Pengembang an bahan ajar harus sesuai dengan tuntutan perkembangan kurikulum. Hal ini sejalan dengan pendapat Rahmi dan Alberida (2017) kurikulum menempati posisi sentral dalam proses pendidikan. Selain itu pengembangan bahan ajar juga harus sesuai dengan per kembangan peserta didik. Pendekatan saintifik pada Kurikulum 2013 menuntut peserta didik untuk berperan aktif dalam proses pembelajaran. Hal ini akan lebih mudah terlaksana jika dipadukan dengan bahan ajar berupa LKPD. Depdiknas (2008) menjelaskan keuntungan penggunaan LKPD ialah dapat mempermudah guru dalam pembelajaran dan membiasakan peserta didik untuk belajar secara mandiri serta memahami dan menjalankan tugas secara tertulis.

Berdasarkan hasil observasi terhadap proses pembelajaran biologi di SMAN 1 Padang pada tanggal 3 Agustus 2017, diketahui pada proses pembelajaran guru telah menerapkan pendekatan saintifik untuk me nuntut partisipasi aktif peserta didik. Tetapi, pada pelaksanaannya belum berjalan secara maksimal, terutama pada kegiatan mengumpul kan informasi. Menurut guru hal ini disebabkan karena sumber belajar yang banyak sehingga membuat peserta didik sulit memilih mana materi yang sesuai dengan tujuan pembelajaran. Selain itu juga karena peseta didik memiliki gaya dan metode belajar yang berbeda-beda. Untuk mengatasi hal tersebut, guru telah 
berupaya memadukan penerapan pendekatan saintifik pada pembelajaran biologi dengan penggunaan LKPD. LKPD yang sudah dikembangkan oleh guru adalah LKPD berbasis problem solving, discovery dan project. Materi LKPD berbasis problem solving yang dikembangkan guru ialah materi pencemaran lingkungan.

Berdasarkan hasil analisis dokumen LKPD yang dikembangkan guru, diketahui bahwa LKPD yang ada masih berupa pertanyaan yang harus dijawab peserta didik. Daftar pertanyaan yang dimuat dalam LKPD juga terlalu banyak, sehingga waktu yang tersedi menjadi tidak cukup. Selain itu, LKPD yang dibuat guru belum memuat pendekatan saintifik. Berdasarkan hal tersebut, maka dikembangkan LKPD berbasis pendekatan saintifik. Menurut guru, Materi biologi yang sulit dipahami oleh peserta didik dalam pembelajaran biologi adalah materi yang berkaitan dengan klasifikasi, terutama materi Kingdom Plantae.

Materi Kingdom Plantae dalam kurikulum 2013 revisi 2016 terdapat pada kelas X KD 3.8 dan 4.8. Cakupan materi Kingdom Plantae meliputi ciri-ciri, metagenesis, klasi fikasi, dan peranan tumbuhan bagi kehidupan. Berdasarkan fakta yang ditemui di lapangan peserta didik mengalami kesulitan dalam memahami perbedaan masing-masing divisi dan kelas pada kingdom plantae sehingga peserta didik menggunakan metode menghafal dalam memahami materi tersebut.

Berdasarkan permasalahan yang ditemukan, maka dilakukan penelitian pengembangan Lembar Kerja Peserta Didik (LKPD materi Kingdom Plantae berbasis pendekatan saintifik untuk peserta didik kelas $\mathrm{X}$ SMA/MA.

\section{METODE PENELITIAN}

Jenis penelitian ini adalah penelitian pengembangan. Penelitian ini menghasilkan LKPD berbasis pendekatan saintifik pada materi Kingdom Plantae untuk peserta didik kelas $\mathrm{X}$ SMA/MA dengan menggunakan 3 tahap model pengembangan $4-D$.

Penelitian ini dilakukan di Jurusan Biologi FMIPA UNP dan SMAN 1 Padang. Waktu pelaksanaan yaitu bulan Februari-April 2018. Produk yang dhasilkan berupa LKPD berbasis pendekatan saintifik pada materi Kingdom Plantae yang telah diuji cobakan pada guru dan peserta didik kelas X SMA Negeri 1 Padang semester genap Tahun Ajaran 2017/2018.

Subjek penelitian ini ialah 28 orang peserta didik kelas X SMAN 1 Padang. Objek penelitian ini adalah LKPD berbasis pendekatan saintifik pada materi Kingdom Plantae untuk peserta didik kelas X SMA/MA. LKPD berbasis pendekatan saintifik divalidasi oleh dua orang dosen jurusan Biologi FMIPA UNP dan dua orang guru Biologi SMAN 1 Padang.

Data penelitian bersumber dari hasil angket validitas dan praktikalitas. Instrumen yang digunakan untuk mengumpulkan data adalah angket validitas dan praktikalitas. Angket validitas berkaitan dengan evaluasi LKPD yang telah dikembangkan. Rahmi, dkk (2018) menjelaskan 4 komponen yang terdapat dalam angket validitas yaitu didaktik, konstruk, teknik, dan bahasa. Angket praktikalitas berkaitan dengan penggunaan LKPD. Angket uji validitas dan praktikalitas disusun berdasarkan skala Likert dengan 4 alternatif jawaban sebagai berikut.

$$
\begin{array}{ll}
\text { SS } & =\text { sangat setuju dengan bobot } 4 \\
\text { S } & =\text { setuju dengan bobot } 3 \\
\text { TS } & =\text { tidak setuju dengan bobot } 2 \\
\text { STS } & \text { = sangat tidak setuju dengan bobot } 1
\end{array}
$$

LKPD ini dikembangkan dengan menggunakan model 4-D (four-D models) yang dikembangkan oleh Thiagarajan et al (1974: 5) yaitu tahap pendefinisian (define), perancangan (design), pengembangan (develop), dan pen desiminasian (disseminate). Mengingat keter batasan waktu dan biaya, maka pada penelitian ini hanya dilakukan sampai tahap pe ngembangan (develop).

\section{Tahap pendefinisian (define)}

Tahap ini bertujuan untuk menetapkan dan mendefinisikan syarat-syarat LKPD. Penetapan syarat-syarat pembelajaran dilakukan dengan menganalisis KI, KD, dan materi pembelajaran berdasarkan standar isi Kurikulum 2013. Tahapan ini meliputi 5 langkah pokok, yaitu (a) analisis awal akhir; (b) analisis peserta didik; (c) analisis tugas; (d) analisis konsep, dan (e) perumusan tujuan pembelajaran.

\section{Tahap perancangan (define)}

Tahap perancangan bertujuan untuk menyiapkan prototipe atau draf dari LKPD yang akan dikembangkan. Tahapan ini terdiri dari 3 
langkah, yaitu: (a) pemilihan media; pemilihan format; dan (c) perancangan awal.

\section{Tahap pengembangan (develop)}

\section{a. Uji Validitas LKPD}

Uji Validitas bertujuan untuk meng evaluasi LKPD yang telah dikembangkan. Uji ini dilakukan dengan memeriksa kesesuaian LKPD dengan Kurikulum 2013, tata bahasa, penyajian, tampilan dan pendekatan saintifik. Uji Validitas dilakukan oleh dua orang dosen jurusan Biologi FMIPA UNP dan dua orang guru SMAN 1 Padang. Validator yang bersedia memvalidasi LKPD dapat dilihat pada Tabel 1.

Tabel 1. Daftar Nama Validator LKPD materi Kingdom Plantae Berbasis Pendekatan Saintifik untuk Peserta Didik Kelas X SMA/MA.

\begin{tabular}{|l|l|l|}
\hline No. & \multicolumn{1}{|c|}{ Nama } & \multicolumn{1}{c|}{ Keterangan } \\
\hline 1. & $\begin{array}{l}\text { Yosi Laila } \\
\text { Rahmi, M. Pd. }\end{array}$ & $\begin{array}{l}\text { Dosen Jurusan Biologi } \\
\text { FMIPA UNP }\end{array}$ \\
\hline 2. & $\begin{array}{l}\text { Ganda Hijrah } \\
\text { Selaras, M. Pd, }\end{array}$ & $\begin{array}{l}\text { Dosen Jurusan Biologi } \\
\text { FMIPA UNP }\end{array}$ \\
\hline 3. & $\begin{array}{l}\text { Asri Yanti, S. Pd, } \\
\text { M. Si. }\end{array}$ & $\begin{array}{l}\text { Guru Biologi SMAN 1 } \\
\text { Padang }\end{array}$ \\
\hline 4. & $\begin{array}{l}\text { Irda Febrina, S. } \\
\text { Pd. }\end{array}$ & $\begin{array}{l}\text { Guru Biologi SMAN 1 } \\
\text { Padang }\end{array}$ \\
\hline
\end{tabular}

Langkah-langkah uji validitas LKPD oleh dosen dan guru adalah sebagai berikut.

1) Meminta kesediaan dosen dan guru untuk melihat kelayakan LKPD serta kebenaran konsep yang telah dibuat.

2) Meminta dosen dan guru untuk memberikan penilaian terhadap LKPD yang dibuat berdasarkan item-item yang ada pada angket uji validitas dan memberikan saran LKPD terhadap tersebut.

3) Setelah penilaian dilakukan, peneliti merevisi LKPD sesuai dengan saran yang diberikan.

b. Uji Praktikalitas LKPD

Uji Praktikalitas bertujuan untuk mengetahui tingkat kepraktisan LKPD saat digunakan dalam proses pembelajaran. Uji praktikalitas dilakukan dengan memberikan angket kepada dua orang guru biologi SMAN 1 Padang dan 28 orang peserta didik kelas $\mathrm{X}$ SMAN 1 Padang. Uji praktikalitas dilakukan dengan langkah-langkah berikut ini.

1) Uji praktikalitas oleh guru

a) Peneliti meminta guru untuk mengisi angket praktikalitas LKPD.

b) Peneliti memberikan LKPD kepada guru c) Peneliti memberikan petunjuk singkat penggunaan LKPD

d) Guru diminta mengisi angket yang sudah berisi pernyataan mengenai LKPD

e) Guru diminta memberikan saran dan kritikan terhadap LKPD

2) Uji praktikalitas oleh peserta didik

a) Peneliti memberikan LKPD kepada peserta didik

b) Peneliti memberikan penjelasan singkat tentang penggunaan LKPD

c) Siswa diminta untuk mengisi LKPD

d) Siswa diminta mengisi angket praktikalitas dan memberikan komentar dan saran terhadap LKPD

Data penelitian dianalisis dengan analisis kualitatif dan kuantitatif. Data untuk tahap pendefinisian dan perancangan dianalisis secara kualitatif serta disajikan dalam bentuk deskriptif. Data dari tahap pengembangan, yakni validitas dan praktikalitas dianalisis secara kuantitatif.

1. Analisis validitas LKPD berbasis pendekatan saintifik

Data validitas didapatkan dengan menganalisis angket validitas yang telah diisi oleh validator. Analisis dilakukan dengan langkah-langkah berikut ini.

a. Memberikan skor jawaban dengan indikator yang berdasarkan skala Likert.

b. Menentukan skor tertinggi

Skor tertinggi $=$ jumlah validator $\mathrm{x}$ jumlah indikator $\mathrm{x}$ skor maksimum

c. Menentukan jumlah skor masing-masing validator dengan menjumlahkan semua skor yang diperoleh dari masing-masing indikator.

d. Menentukan skor yang diperoleh dengan menjumlahkan skor dari masing-masing validator.

e. Penentuan nilai validitas dengan cara berikut ini.

Nilai validitas $=\frac{\text { jumlah skor yang diperoleh }}{\text { jumlah } \text { skor tertinggi }} \times 100 \%$

Memberikan penilaian validitas yang dimodifikasi dari Purwanto (2012) sebagai berikut.

$$
\begin{array}{ll}
90 \%-100 \% & =\text { sangat valid } \\
80 \%-89 \% & =\text { valid }
\end{array}
$$




$$
\begin{array}{ll}
65 \%-79 \% & =\text { cukup valid } \\
55 \%-64 \% & =\text { kurang valid } \\
\leq 54 \% & =\text { sangat tidak valid }
\end{array}
$$

LKPD berbasis pendekatan saintifik pada materi Kingdom Plantae yang dikembang kan pada penelitian ini dianggap valid jika mempunyai nilai validitas $\geq 80 \%$ dan dianggap tidak valid jika mempunyai nilai validitas $<80$ $\%$. Jika pada penelitian nilai validitas tidak mencapai $\geq 80 \%$, maka LKPD berbasis pendekatan saintifik ini akan direvisi oleh peneliti. Jika nilai validitas sudah mencapai mencapai $\geq 80 \%$, maka akan dilanjutkan dengan uji praktikalitas.

2. Analisis praktikalitas LKPD berbasis pendekatan saintifik

Data praktikalitas didapatkan dengan menganalisis angket praktikalitas yang telah diisi oleh guru biologi dan peserta didik. Data praktikalitas penggunaan LKPD dianalisis dengan persentase (\%), menggunakan rumus berikut ini. Nilai praktikalitas $=\frac{\text { Jumlah skor yang diperoleh }}{\text { jumlah skor tertinggi }} \times 100 \%$

Setelah persentase diperoleh, dilakukan pengelompokkan sesuai kriteria yang dimodifikasi dari Purwanto (2012) sebagai berikut.

$$
\begin{array}{ll}
86 \%-100 \% & =\text { sangat praktis } \\
76 \%-85 \% & =\text { praktis } \\
60 \%-75 \% & =\text { cukup praktis } \\
\leq 54 \% & =\text { sangat tidak praktis }
\end{array}
$$

LKPD berbasis pendekatan saintifik yang dikembangkan pada penelitian ini dianggap praktis jika mempunyai nilai praktikalitas $\geq 80 \%$ dan dianggap tidak praktis jika mempunyai nilai praktikalitas $<80 \%$. Jika pada penelitian nilai praktikalitas tidak mencapai $\geq 80 \%$, maka LKPD akan direvisi dan dilakukan uji praktikalitas kembali oleh peneliti.

\section{HASIL DAN PEMBAHASAN}

\section{Hasil}

1. Tahap Pendefinisian (Define)

a. Analisis Awal Akhir

Tahap ini peneliti melakukan wawan cara dan analisis dokumen LKPD yang dibuat guru biologi SMAN 1 Padang. pada tanggal 3 Agustus 2017. Berdasarkan Hasil wawancara diketahui bahwa proses pembelajaran guru telah menerapkan pendekatan saintifik untuk me nuntut partisipasi aktif peserta didik. Tetapi, pada pelaksanaannya belum berjalan secara maksimal, terutama pada kegiatan mengumpul kan informasi. Menurut pendapat guru hal ini disebabkan karena sumber belajar yang banyak sehingga membuat peserta didik sulit memilih materi yang sesuai dengan tujuan pembelajaran, Selain itu juga karena peserta didik memiliki gaya dan metode belajar yang berbeda-beda. Untuk mengatasi hal tersebut guru telah berupaya memadukan penerapan pendekatan saintifik pada pembelajaran biologi dengan penggunaan LKPD.

Berdasarkan hasil anlisis dokumen, diketahui LKPD yang dibuat guru masih berupa pertanyaan yang harus dijawab oleh peserta didik. Daftar pertanyaan yang dimuat dalam LKPD juga terlalu banyak, sehingga waktu yang tersedia menjadi tidak cukup. Selain itu, LKPD yang dibuat oleh guru belum memuat pendekatan saintifik. Selanjutnya menurut guru, materi biologi yang sulit dipahami oleh peserta didik adalah materi yang berkaitan Klasifikasi, terutama materi Kingdom Plantae. Materi ini dianggap terlalu rumit dan sulit untuk dipahami oleh peserta didik. Oleh karena itu, peneliti memberikan alternatif dari permasalahan tersebut dengan mengembangkan LKPD berbasis pendekata saintifik pada materi Kingdom Plantae.

b. Analisis Peserta Didik

Hasil analisis peserta didik melalui observasi diketahui peserta didik yang duduk di kelas X SMA memiliki usia 15-18 tahun. Berdasarkan teori belajar Piaget dalam Budiningsih (2008) pada umur 11-18 tahun berada pada tahap operasional formal dengan ciri pokok perkembangannya sudah mampu berpikir abstrak, logis, menarik kesimpulan, menafsirkan, dan mengembangkan hipotesis. Hasil analisis menjadi asumsi dasar bahwa peserta didik yang duduk di kelas $\mathrm{X}$ telah mampu mengembangkan potensi kognitif dan psikomotor, sehingga telah terampil dalam penggunaan media pembelajaran termasuk bahan ajar seperti LKPD. Selain itu juga peserta didik kisaran usia itu diasumsikan telah mampu menerapkan kegiatan saintifik.

\section{c. Analisis Tugas}

Analisis ini dilakukan untuk merincikan materi pembelajaran yang akan ditulis dalam LKPD. Analisis ini mencakup analisis struktur 
isi yang mencakup analisis KI dan KD untuk materi Kingdom Plantae sehingga dapat dirumuskan indicator pencapaian kompetensi.

d. Analisis Konsep

Pada materi Kingom Plantae konsep yang teridentifikasi adalah ciri-ciri, proses meta genesis, pengklasifikasian tumbuhan, dan peranan tumbuhan. Setelah teridentifikasi konsep-konsep materi Kingdom Plantae, dihasilkanlah tujuan pembelajaran yang diacu dari indikator pencapaian kompetensi yang sesuai dengan Kurikulum 2013.

e. Analisis Tujuan Pembelajaran

Acuan dari perumusan tujuan pembelajaran ini adalah indikator pencapaian kompetensi yang mengacu pada Kurikulum 2013.

2. Tahap Perancangan (Design)

LKPD dikembangkan sesuai dengan langkah-langkah pengembangan yang telah disusun oleh Depdiknas (2008). LKPD ini dibuat menggunakan aplikasi Microsoft Office Publisher 2007. Komponen LKPD meliputi cover, kata pengantar, daftar isi, daftar gambar, daftar tabel, profil LKPD, petunjuk penggunaan, tinjauan kompetensi, uraian materi, lembar kegiatan yang dilengkapi dengan kegiatan saintifik, perlu diingat, motivasi, uji kemampuan, kunci jawaban, pertanyaan kunci dan biografi penulis.

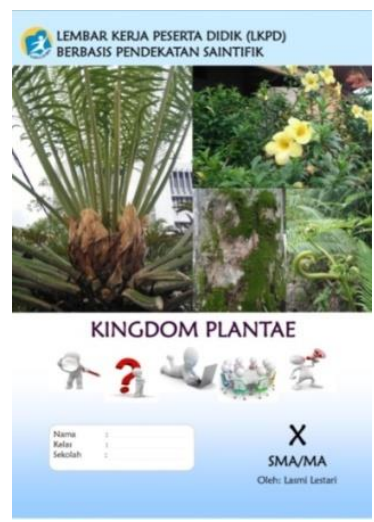

Gambar 1. Tampilan cover LKPD

3. Tahan Pengembangan (Develop)

a. Validasi LKPD

Validasi LKPD berbasis pendekatan saintifik dilakukan oleh 2 orang dosen Jurusan Biologi dan 2 orang guru biologi SMAN 1 Padang. Analisis Validitas LKPD secara ringkas ditampilkan pada Tabel 3.
Tabel 3. Hasil Validasi LKPD Berbasis Pendekatan Saintifik pada Materi Kingdom Plantae

\begin{tabular}{|l|l|l|l|}
\hline No & $\begin{array}{l}\text { Komponen } \\
\text { Penilaian }\end{array}$ & $\begin{array}{l}\text { Nilai } \\
\text { Validitas }\end{array}$ & Kriteria \\
\hline 1 & Kelayakan isi & $87,50 \%$ & Valid \\
\hline 2 & Kebahasaan & $85,94 \%$ & Valid \\
\hline 3 & Penyajian & $83,04 \%$ & Valid \\
\hline 4 & Kegrafikaan & $87,50 \%$ & Valid \\
\hline 5 & $\begin{array}{l}\text { Pendekatan } \\
\text { Saintifik }\end{array}$ & $92,50 \%$ & $\begin{array}{l}\text { Sangat } \\
\text { Valid }\end{array}$ \\
\hline \multicolumn{2}{|l|}{ Rata-rata } & $83,70 \%$ & Valid \\
\hline
\end{tabular}

Hasil validitas LKPD berbasis pendekatan saintifik pada Tabel 3 didapatkan nilai sebesar $87,30 \%$ dengan kriteria valid. Hal ini berarti LKPD berbasis pendekatan saintifik sudah dapat digunakan dalam proses pembelajaran.

b. Praktikalitas LKPD

Uji Praktikalitas LKPD berbasis pen dekatan saintifik dilakukan dengan memberikan angket praktikalitas kepada dua orang guru Biologi dan 28 orang peserta didik kelas $\mathrm{X}$ SMAN 1 Padang. Analisis hasil data uji praktikalitas secara ringkas ditampilkan pada Tabel 4.

Tabel 4. Hasil Praktikalitas LKPD Berbasis Pendekatan Saintifik pada Materi Kingdom Plantae oleh Guru

\begin{tabular}{|l|l|l|l|}
\hline No. & \multicolumn{1}{|c|}{ Aspek } & \multicolumn{1}{|c|}{$\begin{array}{c}\text { Nilai } \\
\text { Praktis } \\
(\%)\end{array}$} & Kriteria \\
\hline 1. & $\begin{array}{l}\text { Kemudahan } \\
\text { Penggunaan }\end{array}$ & 91,67 & $\begin{array}{c}\text { Sangat } \\
\text { praktis }\end{array}$ \\
\hline 2. & $\begin{array}{l}\text { Efisiensi waktu } \\
\text { pembelajaran }\end{array}$ & 83,33 & Praktis \\
\hline 3. & Daya tarik & 87,50 & $\begin{array}{c}\text { Sangat } \\
\text { praktis }\end{array}$ \\
\hline 4. & Manfaat & 81,25 & Praktis \\
\hline Rata-rata & 85,94 & $\begin{array}{c}\text { Sangat } \\
\text { Praktis }\end{array}$ \\
\hline
\end{tabular}

Berdasarkan Tabel 4 diketahui bahwa nilai rata-rata praktikalitas dari LKPD yang dikembangkan adalah 85,94\% dengan kriteria sangat praktis. Hal ini menunjukkan bahwa LKPD yang dikembangkan praktis digunakan oleh guru sebagai salah satu bahan ajar pada materi kingdom plantae.

Uji praktikalitas juga dilakukan oleh peserta didik. Analisis hasil data uji praktikalitas oleh peserta didik secara ringkas ditampilkan pada Tabel 5 . 
Tabel 5. Hasil Praktikalitas LKPD Berbasis Pendekatan Saintifik pada Materi Kingdom Plantae oleh Peserta Didik

\begin{tabular}{|l|l|c|c|}
\hline No. & \multicolumn{1}{|c|}{ Aspek } & $\begin{array}{c}\text { Rata-rata } \\
\text { nilai praktis }\end{array}$ & Kriteria \\
\hline 1. & $\begin{array}{l}\text { Kemudahan } \\
\text { Penggunaan }\end{array}$ & $87,38 \%$ & $\begin{array}{l}\text { Sangat } \\
\text { praktis }\end{array}$ \\
\hline 2. & $\begin{array}{l}\text { Efesiensi waktu } \\
\text { pembelajaran }\end{array}$ & $80,36 \%$ & Praktis \\
\hline 3. & Daya tarik & $81,70 \%$ & Praktis \\
\hline 4. & Manfaat & $82,74 \%$ & Praktis \\
\hline & Rata-rata & $83,05 \%$ & Praktis \\
\hline
\end{tabular}

Berdasarkan Tabel 5 diketahui nilai ratarata praktikalitas LKPD berbasis pendekatan saintifik oleh peserta didik adalah 83,05\% dengan kriteria praktis. Hal ini menunjukkan bahwa LKPD yang dikembangkan praktis digunakan oleh peserta didik dalam pem belajaran.

\section{A. Pembahasan}

\section{Validitas LKPD}

Analisis data dari angket validitas LKPD berbasis pendekatan saintifik oleh dosen dan guru didasarkan pada lima komponen, yaitu kelayakan isi, kebahasaan, penyajian, kegrafik an, dan pendekatan saintifik. Hasil analisis data menunjukkan bahwa LKPD berbasis pendekatan saintifik mempunyai nilai rata-rata validitas sebesar 87,30\% dengan kategori valid.

Ditinjau dari komponen kelayakan isi, LKPD dinyatakan valid dengan nilai $87,50 \%$, artinya LKPD yang dikembangkan telah sesuai dengan kurikulum yang berlaku, yaitu Kurikulum 2013. Depdiknas (2008) yang menyatakan bahan ajar yang dikembangkan harus sesuai dengan tuntutan kurikulum.

Ditinjau dari komponen kebahasaan, LKPD dinyatakan valid dengan nilai $85,94 \%$. Komponen kebahasaan berkenaan dengan penggunaan kalimat yang jelas dan tidak menimbulkan kerancuan bagi peserta didik. Menurut Depdiknas (2008) bahan ajar harus memuat kalimat yang jelas, kalimat tidak terlalu panjang. LKPD ini telah beberapa kali mengalami revisi dalam aspek kebahasaan. Berdasarkan nilai validitas dari aspek kebahasaan, LKPD berbasis pendekatan saintifik sudah menggunakan Bahasa Indonesia yang baik dan benar.

Ditinjau dari komponen penyajian, LKPD dinyatakan valid dengan nilai $83,04 \%$, artinya
LKPD telah disajiakan secara sistematik, memuat rincian materi dan tujuan pembelajaran yang jelas, mampu menunjang kelancaran proses pembelajaran, memuat motivasi, stimulus dan respon. Depdiknas (2008) menjelaskan komponen penyajian mencakup kejelasan tujuan yang ingin dicapai, urutan sajian, daya tarik dan kelengkapan informasi.

Ditinjau dari komponen kegrafikaan, LKPD dinyatakan valid dengan nilai $87,50 \%$. Komponen kegrafikaan berhubungan dengan tampilan LKPD yang memuat tampilan jenis dan ukuran huruf yang jelas dan menarik, Lay out (tata letak), gambar dan desain LKPD menarik. Materi disajikan dengan tulisan dan jenis huruf yang jelas. Menurut Depdiknas (2008: 18), huruf yang digunakan dalam bahan ajar cetak tidak boleh terlalu kecil dan mudah dibaca. Selain itu pemilihan warna background kontras dengan huruf sehingga tulisan mudah dibaca. Pada bagian-bagian khusus seperti perlu diingat dan motivasi digunakan tulisan yang berbeda sehingga lebih menarik untuk membacanya.

Ditinjau dari komponen pendekatan saintifik, LKPD dinyatakan sangat valid dengan nilai $92,50 \%$. Hal ini membuktikan bahwa LKPD telah memuat lima kegiatan saintifik, yaitu mengamati menanya, mengumpulkan informasi, mengasosiasikan dan mengomunikasi kan. LKPD berbasis pendekatan saintifik juga dikatakan valid dalam meningkatkan keaktifan peserta didik dalam belajar, karena kegiatan saintifik akan merangsang rasa ingin tahu peserta didik dalam menemukan jawaban atas pertanyaannya. Hal ini sesuai dengan pendapat Marjan (2014) pembelajaran menggunakan pendekatan saintifik dapat meningkatkan keaktifan peserta didik dan penelitian Janbuala (2013) yeng menemukan bahwa di dalam pembelajaran saintifik dapa meningkatkan keterampilan proses sains anak.

Secara keseluruhan, nilai hasil uji validitas LKPD berbasis pendekatan saintifik adalah $87,30 \%$. Oleh karena itu, dapat dikatakan bahwa LKPD berbasis pendekatan saintifik pada materi Kingdom Plantae yang dikembangkan telah valid dan dapat digunakan pada pembelajaran biologi.

\section{Praktikalitas LKPD}

Uji praktikalitas ini melibatkan 2 orang guru dan 28 orang peserta didik kelas X SMAN 1 Padang. Berdasarkan analisis angket praktikalitas oleh guru terhadap LKPD diketahui 
bahwa LKPD dikategorikan sangat praktis dengan nilai $85,94 \%$. Hasil uji praktikalitas oleh peserta didik didapatkan kategori praktis dengan nilai $83,05 \%$.

Ditinjau dari aspek kemudahan pengguna an, LKPD sangat praktis menurut guru dengan nilai 91,67\% dan peserta didik dengan nilai $87,38 \%$. Hal ini menunjukkan bahwa LKPD yang dikembangkan telah menyajikan materi dengan jelas, sederhana, keseluruhan isi LKPD mudah dipahami, ukuran dan jenis huruf mudah dibaca, memiliki ukuran yang praktis dan dilengkapi dengan petunjuk umum yang jelas. Hal ini sesuai dengan BNSP (2013) yang menyatakan standar bahasa atau keterbacaan dalam bahan ajar meliputi penggunaan Bahasa Indonesia yang baik dan benar, kejelasan bahasa dan kemudahan untuk dibaca.

Ditinjau dari aspek efisiensi waktu pembelajaran, LKPD memiliki nilai praktis menurut guru dengan nilai $83,33 \%$ dan peserta didik dengan nilai $80,36 \%$. Kriteria praktis ini menunjukkan bahwa LKPD yang dikembangkan efisien digunakan dalam pembelajaran. Waktu pembelajaran lebih efisien dan siswa dapat belajar sesuai dengan kemampuannya. Menurut Sumiati dan Asra (2007) LKPD dapat membantu peserta didik untuk memproses hasil belajar (menemukan dan membuktikan konsep yang dipelajari) sesuai dengan kemampuannya.

Ditinjau dari aspek daya tarik, LKPD memiliki nilai sangat praktis menurut guru dengan nilai $87,50 \%$ dan praktis menurut peserta didik dengan nilai $81,70 \%$. Hal ini menunjukkan bahwa LKPD saintifik yang dikembangkan dapat membuat waktu pembelajaran menjadi lebih efisien dan siswa dapat belajar sesuai dengan kemampuannya. Menurut Sukardi (2008), salah satu pertimbangan praktis yang perlu diperhatikan ialah waktu yang diperlukan untuk proses penggunaan instrumen buatan sendiri sebaiknya singkat, cepat dan tepat.

Ditinjau dari aspek manfaat, LKPD memiliki nilai praktis menurut guru dengan nilai $81,25 \%$ dan peserta didik dengan nilai $82,74 \%$. Hal ini berarti LKPD dapat mebantu guru sebagai fasilitator dan membantu siswa memahami konsep dengan kegiatan saintifik. Menurut Majid (2012: 177), LKPD dapat memudahkan guru dalam menyiapkan dan melaksanakan pembelajaran, membantu peserta didik belajar memahami materi dan menjalankan sesuatu secara tertulis.
Secara keseluruhan LKPD yang dikembangkan memiliki kriteria praktis oleh guru dan peserta didik. Hal ini berarti LKPD mudah digunakan, waktu pembelajaran menjadi lebih efisien, memiliki daya tarik dan bermanfaat.

\section{KESIMPULAN}

1. LKPD berbasis pendekatan saintifik yang dikembangkan memiliki nilai validitas sebesar $87,30 \%$ dengan kriteria valid.

2. LKPD berbasis pendekatan saintifik yang dikembangkan memiliki nilai praktikalitas sebesar $85,94 \%$ oleh guru dengan kriteria sangat praktis dan $83,05 \%$ oleh peserta didik dengan kriteria praktis.

\section{DAFTAR PUSTAKA}

BNSP. (2013). Kegiatan Penilaian Buku Teks Pelajaran Pendidikan Dasar dan Menengah. Jakarta: Departemen Pendidikan Nasional.

Budiningsih, A. (2008). Belajar dan Pembelajaran. Jakarta: PT. Rineka Cipta.

Depdiknas. (2008). Panduan Pengembangan Bahan Ajar. Jakatra: Departemen Pendidikan Nasional Direktorat Jendral Menajemen Pendidikan Dasar dan Menengah.

Hosnan. (2014). Pendekatan Saintifik dan Kontekstual dalam Pembelajaran Abad 21 (Kunci Sukses Implementasi Kurikulum 2013). Bogor: Penerbit Ghalia Indonesia.

Janbuala, S. et. al. (2013). A Study of Using Instructional Media to Enhance Scientific Process Skill for Young Children in Child Development Centers in Northeastern Area. Jurnal International Forum of Teaching and Studies. Universitas Thailand.

Lampiran Permendikbud No. 81A. 2013. Implementasi Kurikulum (Salinan Lampiran IV). Jakarta: Kementerian Pendidikan dan Kebudayaan.

Majid, A. (2012). Perencanaan Pembelajaran. Bandung: PT Remaja Rosdakarya.

. (2014). Implementasi Kurikulum 2013. Bandung: Interes Media.

Marjan, J., dkk. (2014). Pengaruh Pembelajaran dengan Pendekatan 
Saintifik Terhadap Hasil Belajar Biologi dan Keterampilan Proses Sains Siswa Ma Mu'alimat Nw Pancor Selong Kabupaten Lombok Timur Nusa Tenggara Barat. E-Journal Program Studi Pasca sarjana Universitas Guruan Ganesha. Vol 4. Program Studi Guruan IPA. Program Pascasarjana Universitas Guruan Ganesha Singaraja.

Mulyasa. (2013). Pengembangan dan Implementasi Kurikulum 2013. Bandung: PT Remaja Rosdakarya.

Purwanto, N. (2012). Prinsip-prinsip dan Teknik Evaluasi Pengajaran. Bandung: PT Remaja Rosdakarya.

Rahmi, L.Y., \& Alberida, H. (2017). Improving Students' Higher Order Thinking Skills through Portfolio Assessment on Biology Curriculum and Textbook Analysis Course. Bioeducation Journal. 1 (1), 22-33.

Rahmi, Y. L., Ardi, A., \& Novriyanti, E. (2017). The Validity of Guided Inqury-Based
Teaching Materials on Management and Technique Laboratory. Bioeducation Journal, 1(2), 10-17.

Rahmi, Y. L., Novriyanti, E., Ardi, A., \& Rifandi, R. (2018, April). Developing Guided Inquiry-Based Student Lab Worksheet for Laboratory Knowledge Course. In IOP Conference Series: Materials Science and Engineering (Vol. 335, No. 1, p. 012082). IOP Publishing.

Sumiati \& Asra. (2007). Metode Pembelajaran. $\quad$ Bandung: $\mathrm{CV}$. Wacana Prima.

Sukardi. (2012). Evaluasi Pendidikan Prinsip dan Operasionalnya. Jakarta: PT Bumi Aksara.

Thiagarajan, S. et al. (1947). Instructional Development for Training Teachers of Exceptional Children. Minnesota: University of Minnesota. 